\title{
A Reappraisal of the Terverticillate Penicillia Using Biochemical, Physiological and Morphological Features III. An Evaluation of Pectinase and Amylase Isoenzymes for Species Characterization
}

\author{
By R. R. M. PATERSON, ${ }^{1}$ P. D. BRIDGE, ${ }^{1}$ M. J. CROSSWAITE ${ }^{2} \dagger$ \\ AND D. L. HAWKSWORTH ${ }^{1 *}$ \\ ${ }^{1} C A B$ International Mycological Institute, Ferry Lane, Kew, Surrey TW9 3AF, UK \\ ${ }^{2}$ Department of Biology, King's College London, University of London, London W8 7AH, UK
}

(Received 20 January 1989; revised 15 June 1989; accepted 17 July 1989)

\begin{abstract}
Polyacrylamide gel electrophoresis of extracellular pectinase and amylase isozymes of 170 mainly terverticillate Penicillium strains was undertaken. The data were coded and subjected to numerical analysis. Variation in intensity of isozymes was observed in repeat analyses of some strains, although most were consistent. Variation was also observed between some representative strains of species. $P$. viridicatum was more variable than $P$. brevicompactum and $P$. hordei for intensity of pectinase activity. There was a correlation between the grouping of the strains on the basis of the isozymes and the species concepts only in some cases. The method proved useful for the identification of strains producing intense activity which provided clear patterns, for example, $P$. brevicompactum and $P$. chrysogenum and to a lesser extent $P$. solitum var. crustosum and $P$. hordei. The method was also exclusionary in that some species were restricted to a particular cluster or subcluster. Amylase patterns confirmed that strains referred to as single species are not all homogeneous genetically, and that some strains are not simply haploid homokaryons. The genetic heterogeneity of the strains explains some of the problems in the systematics of the terverticillate penicillia.
\end{abstract}

\section{INTRODUCTION}

Isozyme analysis has been recommended as of possible assistance in the systematics and genetics of fungi (Garber \& Beraha, 1966; Mays et al., 1979; Micales et al., 1986). The technique has been applied in studies of protoplast fusion hybrids of Penicillium chrysogenum and P. roquefortii (Anné \& Peberdy, 1981). A genetic interpretation of the electrophoresis of pectolytic enzymes of three phytopathogenic penicillia has been reported (Garber \& Beraha, 1966). Extracellular pectinases have been used for an initial grouping of Penicillium strains and confirmed subsequently by amylase and ribonuclease isozymes (Cruickshank \& Pitt, 1987). This paper reports on electrophoretic analyses of extracellular pectinase and amylase isozymes from 171 of the 348 strains studied in a multidisciplinary systematic study (Bridge et al., 1989) in order to test the validity of this approach to species identification in this genus, and also to explore further the homogeneity of the groupings.

\section{METHODS}

The material and methods used for the growth of the fungi, and electrophoresis, were adapted from Cruickshank \& Pitt (1987). The main modifications were (a) different electrophoresis tank and cooling system, (b) thinner gels, $(c)$ using filter paper for sample application, and $(d)$ different amylase production medium.

† Present address: 25 Oatlands Drive, Harrogate, North Yorkshire HG2 8JT, UK.

Abbreviations: OTU, operational taxonomic unit; PB, pectin broth; WB, wheat-grain broth; PE, pectin esterase; PG, polygalacturonase; PL, pectin lyase. 


\section{Table 1. Strains present in clusters and subclusters}

IMI numbers are the accession numbers of the CAB International Mycological Institute; IMI numbers with the same superscript number represent duplicated strains. ${ }^{\mathrm{T}}$ denotes ex-type strains. Species names followed by a number in parentheses indicate the species cluster in Bridge et al. (1989). 'Penicillium sp.' refers to strains in Bridge et al. (1989).

Species name

la $P$. solitum var. crustosum $P$. solitum var. solitum

lb $P$. atramentosum

$P$. aurantiogriseum (6)

$P$. citrinum

$P$. expansum (2)

$P$. solitum var. solitum

$P$. viridicatum (27)

Penicillium sp.

1c P. solitum var. crustosum

1d $P$. atramentosum

2a $P$. citrinum

$P$. solitum var. solitum

P. solitum var. crustosum

2b $P$. aurantiogriseum (4)

2c $P$. granulatum

$P$. solitum var. crustosum

$P$. solitum var. solitum

2d P. aurantiogriseum (6)

$P$. solitum var. solitum

Penicillium sp.

2e Penicillium sp.

2f $P$. aurantiogriseum (4)

$P$. brevicompactum

$P$. expansum (1)

$P$. expansum (3)

$P$. solitum var. solitum

Penicillium sp.

3a $P$. aurantiogriseum (4)

P. echinulatum

$P$. solitum var. crustosum

$P$. solitum var. solitum

$P$. griseofulvum

3b $P$. funiculosum

3c $P$. chrysogenum (14)

$P$. echinulatum

$P$. solitum var. solitum

$P$. griseofulvum

$P$. hordei

$P$. verrucosum

3d P. chrysogenum (7)

$P$. chrysogenum (14)

3e $P$. roquefortii

3f $P$. brevicompactum

$3 \mathrm{~g} \quad P$. solitum var. crustosum $P$. hordei

3h $P$. echinulatum

$P$. verrucosum

P. psittacinum
IMI no.

296938

169087a, 293179, 297892

$210922,{ }^{1} 210922,{ }^{1} 293209,298080$

297894

$39812^{\mathrm{T}}$

246656, 279025, 285524

49096, 285507, 297956, 297999

$39758 \mathrm{iii}^{\mathrm{T}}{ }^{*} 150406,{ }^{*} 173209,284414,293194,293197,294408$

297903

293196

297983

921961,*280297

39811, 206416, 209783, 265297, 287746, 291196, 291198, 291199, 291547

209889, 262791, 295697

297547

$40220^{\mathrm{T}}$

$28040,89378,89385,91939,{ }^{2} 91939,{ }^{2} 143321,181050,229439,293722,295696$,

$296059, * 297891^{*}$

$40218,68235,92264,291197$

92222

92225, 298007

293178

19759

$89372,{ }^{\text {T* }} 297957$

$39824,{ }^{\mathrm{T}} 297950$

28619, 232297, 285521, 297898, 297899*

297959, 299046

$34911,39810,89386,92224$

89312

89374

$68236,{ }^{3} 285508$

39808, 52736, 293182

$51355,68234,92276,154731,194737,291543,{ }^{*} 297980$

92273

$193019^{\mathrm{T} *}$

296926, 297895

281776

39766, 39822, 293201

297542

151748, 286971, 291539*

284409

$24314,{ }^{\mathrm{T} *} 39762 \mathrm{iii}$

91020b, 279567, 297551

$24313^{\mathrm{T} *}$

$40225,17456,{ }^{4} 17456,{ }^{4} 92044,94149,192502,200408,285220,295048$

281551

$40213,^{\mathrm{T} *} 297900,297906$

$40028,{ }^{\mathrm{T}} 297554$

295050,297897

$192904^{\mathrm{T}}$ 
Table 1 (continued)

\begin{tabular}{|c|c|c|}
\hline & Species name & IMI no. \\
\hline $3 \mathrm{i}$ & P. chrysogenum (7) & 91935 \\
\hline $3 \mathrm{j}$ & $\begin{array}{l}P . \text { solitum var. solitum } \\
P \text {. hirsutum }\end{array}$ & $\begin{array}{l}297969 \\
196570\end{array}$ \\
\hline $3 \mathbf{k}$ & P. griseofulvum & $28808,39809,297893,297901$ \\
\hline 31 & $\begin{array}{l}P . \text { atramentosum } \\
P . \text { verrucosum }\end{array}$ & $\begin{array}{l}297984 \\
186092,285522,295238,297896\end{array}$ \\
\hline $4 a$ & $\begin{array}{l}\text { P. solitum var. solitum } \\
P . \text { griseofulvum } \\
P . \text { hirsutum } \\
P . \text { hordei }\end{array}$ & $\begin{array}{l}297556 \\
285525 \\
285512 \\
223651,246204,264173,284723,296066\end{array}$ \\
\hline $4 b$ & $\begin{array}{l}P . \text { aurantiogriseum }(4) \\
P . \text { chrysogenum }(14) \\
P . \text { viridicatum }(28)\end{array}$ & $\begin{array}{l}286763,291195 \\
37767 \\
293187\end{array}$ \\
\hline $4 c$ & $\begin{array}{l}P . \text { verrucosum } \\
P . \text { viridicatum }(28)\end{array}$ & $\begin{array}{l}260915 \\
265301\end{array}$ \\
\hline 5 & Penicillium sp. & 285511 \\
\hline 6 & P. chrysogenum (14) & 92220 \\
\hline 7 & P. verrucosum & 285523 \\
\hline \multicolumn{3}{|c|}{ Negative pectinase and amylase strains } \\
\hline & $\begin{array}{l}\text { echinulatum } \\
\text { solitum var. crustosum } \\
\text { griseofulvum } \\
\text { olivinoviride } \\
\text { verrucosum } \\
\text {. viridicatum (27) } \\
\text { enicillium } \mathrm{sp} \text {. }\end{array}$ & $\begin{array}{l}68236^{3} \\
206159,262790,243053 \\
296934 \\
40223^{T} \\
284410 \\
192905,297907 \\
39752,75832\end{array}$ \\
\hline
\end{tabular}

* DNA base compositions of these strains have been determined by Paterson et al. (1989).

Maintenance and growth of fungal isolates. The Penicillium isolates used in this study are given in Table 1. Each strain was assigned a project number so that the identity of strains was not known at the time of the analysis. Strains were stored at $-20^{\circ} \mathrm{C}$ on Czapek-Dox Agar (Smith \& Onions, 1983) slopes, inoculated onto Malt Extract Agar (Smith \& Onions, 1983), and grown for $7 \mathrm{~d}$ at $25^{\circ} \mathrm{C}$. These were used to inoculate liquid media for the production of enzymes.

Enzyme production. For the production of pectinase, cultures were inoculated using a sterile needle into $2 \mathrm{ml}$ pectin broth (PB) in a $5 \mathrm{ml}$ Bijoux bottle. PB contained $0.9 \mathrm{~g}\left(\mathrm{NH}_{4}\right) \mathrm{H}_{2} \mathrm{PO}_{4}, 2.0 \mathrm{~g}\left(\mathrm{NH}_{4}\right)_{2} \mathrm{HPO}_{4}, 0.1 \mathrm{~g}$ $\mathrm{MgSO}_{4} .7 \mathrm{H}_{2} \mathrm{O}, 0.5 \mathrm{~g} \mathrm{KCl}$ (all BDH), and $10.0 \mathrm{~g}$ citrus pectin (Sigma) in 1 litre of distilled water. For amylase production, wheat-grain broth (WB) [1 rolled wheat grain (about $0.6 \mathrm{~g}$ ) (Holland \& Barratt, UK), in $2 \mathrm{ml}$ of distilled water in a $5 \mathrm{ml} \mathrm{Bijoux} \mathrm{bottle]} \mathrm{was} \mathrm{inoculated} \mathrm{in} \mathrm{the} \mathrm{same} \mathrm{way.} \mathrm{All} \mathrm{cultures} \mathrm{were} \mathrm{grown} \mathrm{at} 25^{\circ} \mathrm{C}$ in the dark for $7 \mathrm{~d}$. Similar quantities of inocula as judged by visual estimation were used for all inoculations.

Electrophoresis. The gel buffer for both pectinase and amylase was $0.525 \mathrm{~g}$ citric acid monohydrate and $4.598 \mathrm{~g}$ Tris in 1 litre of distilled water. Constituents of the gel were citrus pectin or starch, $0 \cdot 1 \mathrm{~g}$; acrylamide, $10 \mathrm{~g}$; bisacrylamide, $0.25 \mathrm{~g}$; TEMED $\left(N, N, N^{\prime}, N^{\prime}\right.$-tetramethylethylenediamine $), 0.1 \mathrm{ml}$; ammonium persulphate, $0.1 \mathrm{~g}$; gel buffer, $100 \mathrm{ml}$. The electrode buffer contained $7.22 \mathrm{~g}$ boric acid and $15.75 \mathrm{~g}$ sodium tetraborate decahydrate in 1 litre of distilled water (Cruickshank \& Wade, 1980). A Shandon-Southern V500/150 power pack, and a CAMAG water-cooled horizontal electrophoresis tank were used. Gels were made in a Shandon mould $(216 \times 144 \times 2 \mathrm{~mm})$, and divided to give gels $216 \times 72 \times 2 \mathrm{~mm}$. The gel was placed on a $2 \mathrm{~mm}$ thick glass plate secured to the electrophoresis cooling platen by silicone grease to enhance cooling. Samples $(15 \mu 1)$ of the spent PB for pectinase and WB for amylase were applied to Whatman $3 \mathrm{MM}$ chromatography paper $(5 \times 5 \mathrm{~mm})$; the paper pieces were placed on the gel $1 \mathrm{~cm}$ from the lower edge and $5 \mathrm{~mm}$ apart. Two superimposed squares were used per sample. Protein concentrations were not determined (Cruickshank \& Pitt, 1987). Bromophenol blue (0.05\%, w/v) was applied to the middle and to both extreme tracks of the gels. A constant current of $12 \mathrm{~mA}$ was applied and stopped when the dye had moved $5 \mathrm{~cm}$ (about $2 \mathrm{~h}$ ).

Enzyme staining. After electrophoresis pectin gels were submerged in $0.1 \mathrm{M}$-malic acid for $1 \mathrm{~h}$, rinsed in distilled water, and stained overnight in $0.01 \%(\mathrm{w} / \mathrm{v})$ ruthenium red at $4{ }^{\circ} \mathrm{C}$. The gel was rinsed for $1 \mathrm{~h}$ with three changes of distilled water, and the results recorded by visual examination and by photographic record. The gel was then 
submerged in ammonium persulphate $(0.1 \%, \mathrm{w} / \mathrm{v})$ for $30 \mathrm{~min}$, and results recorded as above. Polygalacturonase (PG) activity gave transparent bands or zones, pectin esterase (PE) activity gave dark zones, and pectin lyase (PL) gave yellow zones (Cruickshank \& Wade, 1980).

Starch gels were placed in $0.1 \mathrm{M}$-sodium acetate buffer, $\mathrm{pH} 5.5$, containing $0.1 \mathrm{~g}$ sodium azide $1^{-1}$, for $2 \mathrm{~h}$ at room-temperature, rinsed in distilled water and then stained overnight at $4{ }^{\circ} \mathrm{C}$ in $1.5 \%(\mathrm{w} / \mathrm{v})$ potassium iodide, $0.005 \%(w / v)$ iodine. Photographic prints and drawings of gels were used to assess the enzyme bands which appeared transparent against blue-stained starch.

Reproducibility. It was considered particularly important to assess consistency of pectinase production because pectinase activity was used by Cruickshank \& Pitt (1987) for identifying species. Other enzymes were used to confirm results. The pectinase analysis was repeated on $\mathbf{4 5}$ strains by regrowing and testing, up to five times, on different dates under identical conditions to assess the reproducibility of the technique (Table 2). Also, four strains were represented twice in the complete test group, and were analysed as separate cultures for both pectinase and amylase.

Band/pattern assessment and coding. Patterns and bands were categorized initially as either no band, too faint, adequate or strong, and were assigned the values $0,1,2$ or 3 respectively. Only those assigned 2 and 3 were assessed for similarity to others on the basis of shape of patterns and/or $R_{F}$ values of bands, and were coded accordingly using a binary code. The faint(1) patterns/bands could not be accurately assesssed for similarity to others. Therefore, values 0 and 1 were effectively negative and 2 and 3 positive. PL activity was difficult to assess and was only recorded as present or absent. $\boldsymbol{R}_{F}$ values were obtained by dividing the distance moved from the origin of the furthest edge of the pattern/band by the distance moved by the dye-front $(5 \mathrm{~cm})$. A data matrix was constructed for seven PG patterns (i.e. a-d, g, h and j; Fig. 1), for 12 pectinase and amylase bands (Fig. 1), for presence or absence of PL and 160 strains [OTUs (operational taxonomic units)]. Resemblances were calculated using Jaccard's coefficient and clustered by average linkage (UPGMA; Sneath \& Sokal, 1973).

The dendrogram obtained was divided into clusters and subclusters in the manner of Hamamoto et al. (1986) for enzyme mobilities, i.e. a particular similarity level was not chosen to determine all groupings. In some cases, subclusters and clusters were grouped because they had enzyme activities typical of the grouping, although the overall similarity was low. Also, if strains were obviously different from a group, as determined by other methods, they were excluded, although percentage similarity to that group may have been high.

\section{RESULTS}

\section{Reproducibility}

The data obtained for repeated analysis of pectinase are presented in Table 2. Similar patterns/bands were obtained from repeated analysis of individual strains where enzyme level was assessed as 2 or 3 . The mean \pm SD of positive pectinase results for all 45 strains was $72 \% \pm 32 \cdot 9$. Consistently positive pectinase results (levels 2 and 3 ) were observed from $23(51 \%)$ strains, and consistently negative results (levels 0 and 1$)$ were observed for four $(9 \%)$ strains. The remaining $18(40 \%)$ strains showed variable results for intensity (i.e. a combination of levels 0,1 , 2 and 3 ) and gave a mean \pm SD of $53 \% \pm 12.5$ positive results on repeat analyses. Of these 18 strains, equal numbers of positive and negative results were obtained from eight strains, and so were $100 \%$ variable. The remaining 10 strains gave consistent results from $67 \% \pm 3.5$ of the analyses of each strain.

In summary, $27(60 \%)$ strains gave $100 \%$ consistent results, $10(22 \%)$ gave results with a mean \pm SD of $67 \% \pm 3.5$ consistency, and $8(12 \%)$ gave results which were equally positive and negative (i.e. $100 \%$ variable). Therefore, a mean percentage value for consistent results is $60 \%+(22 \times 67 \%)=75 \%$.

Eight $(80 \%) P$. brevicompactum strains were consistently positive, and two (20\%) strains gave equal numbers of positive and negative results from a mean \pm SD of $2 \pm 0.3$ tests per strain. This gives a consistency value of $80 \%$. The duplicated strain (IMI 17456) was consistently positive.

Six $(54 \%) P$. hordei strains were consistently positive and four $(36 \%)$ strains gave a mean \pm SD of $67 \% \pm 0.0$ consistent results; one $(9 \%)$ strain gave equal numbers of positive and negative results from a mean \pm SD of $3 \pm 0.7$ tests per strain. This gives a consistency value of $78 \%$.

Three $(27 \%) P$. viridicatum strains gave consistently positive results and two (18\%) gave consistently negative results; four $(36 \%)$ strains gave a mean \pm SD of $65 \% \pm 3.5$ consistent results, and two (18\%) gave equal numbers of positive and negative results from a mean \pm SD of $3 \pm 0.8$ tests per strain. This gives a consistency value of $68 \%$. 


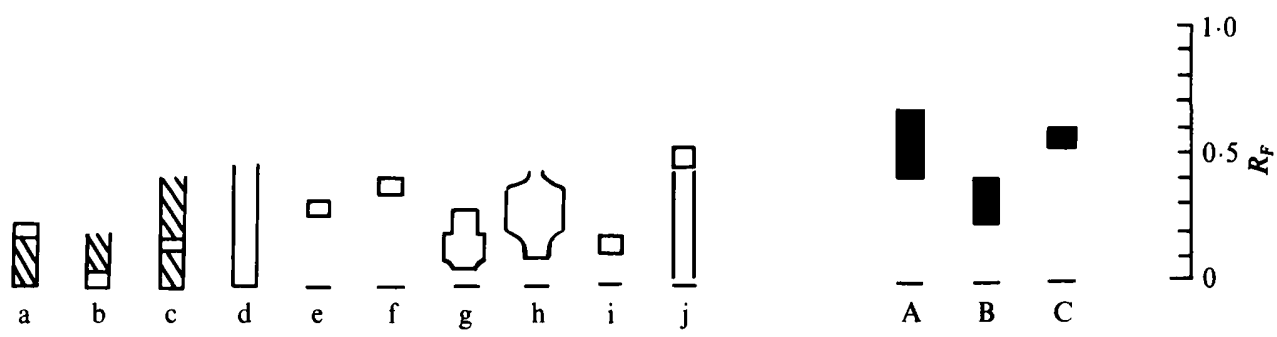

Fig. 1. Schematic representations of isozyme patterns and bands. (a-j), PG patterns/bands, seen as transparent zones in the red-stained gel; shaded regions represent less intense zones of clearing. A-C, PE patterns, which stained dark. PL activity was difficult to observe; it was recorded as simply absent or present, and is not represented in this figure.

\section{Table 2. Variation in intensity of pectinase production}

After visual examination of gels or photographic prints, patterns and bands were designated as follows: 1 , too faint; 2 , average; 3 , strong. Intensities 0 and 1 were considered negative. All patterns and bands from the same strain which were coded as 2 or 3 were of a similar shape or had similar $R_{F}$ values.

\begin{tabular}{|c|c|c|c|c|c|c|c|}
\hline Species & IMI no. & Intensity & $\begin{array}{l}\text { Percentage } \\
\text { consistent } \\
\text { analysis }\end{array}$ & Species & IMI no. & Intensity & $\begin{array}{l}\text { Percentage } \\
\text { consistent } \\
\text { analysis }\end{array}$ \\
\hline P. aurantiogriseum & 89372 & 1,2 & 0 & P. hordei & 284723 & $2,2,2$ & 100 \\
\hline \multirow[t]{3}{*}{ P. brevicompactum } & $\begin{array}{l}17456 \\
17456 \\
94149 \\
285220\end{array}$ & $\begin{array}{l}2,3 \\
2,3 \\
2,3 \\
2,3\end{array}$ & $\begin{array}{l}100 \\
100 \\
100 \\
100\end{array}$ & & $\begin{array}{l}264173 \\
291539 \\
223651 \\
297906\end{array}$ & $\begin{array}{l}2,2,3 \\
2,2,2,2 \\
1,2 \\
1,1,2\end{array}$ & $\begin{array}{r}100 \\
100 \\
0 \\
67\end{array}$ \\
\hline & $\begin{array}{l}192502 \\
40225\end{array}$ & $\begin{array}{l}0,3 \\
2,3,3\end{array}$ & $\begin{array}{r}0 \\
100\end{array}$ & $\begin{array}{l}\text { P. solitum var. } \\
\text { crustosum }\end{array}$ & 281551 & $1,2,3$ & 67 \\
\hline & $\begin{array}{l}200408 \\
92044 \\
295048 \\
297950\end{array}$ & $\begin{array}{l}2,3 \\
2,3 \\
2,3 \\
0,3\end{array}$ & $\begin{array}{r}100 \\
100 \\
100 \\
0\end{array}$ & $\begin{array}{l}\text { P. solitum var. } \\
\text { solitum }\end{array}$ & $\begin{array}{l}297891 \\
296059 \\
52736\end{array}$ & $\begin{array}{l}2,3 \\
3,3 \\
1,1\end{array}$ & $\begin{array}{l}100 \\
100 \\
100\end{array}$ \\
\hline P. chrysogenum & $\begin{array}{l}297895 \\
24314\end{array}$ & $\begin{array}{l}2,2 \\
0,1,1\end{array}$ & $\begin{array}{l}100 \\
100\end{array}$ & P. viridicatum & $\begin{array}{l}39758 \mathrm{ii} \\
173209\end{array}$ & $\begin{array}{l}0,1,2,2,2 \\
2,2,2\end{array}$ & $\begin{array}{r}60 \\
100\end{array}$ \\
\hline P. citrinum & $\begin{array}{l}92196 \\
39812\end{array}$ & $\begin{array}{l}2,2 \\
1,3\end{array}$ & $\begin{array}{r}100 \\
0\end{array}$ & & $\begin{array}{l}284408 \\
284414 \\
150406\end{array}$ & $\begin{array}{l}2,2,2 \\
1,1,2 \\
1,1,2,2\end{array}$ & $\begin{array}{r}100 \\
67 \\
0\end{array}$ \\
\hline P. expansum & 297899 & $3,2,2,1$ & 75 & & 265301 & $2,2,2$ & 100 \\
\hline$P$. hirsutum & 285512 & $2,2,3$ & 100 & & 293187 & $2,2,1$ & 67 \\
\hline P. hordei & $\begin{array}{l}246204 \\
296066 \\
297900 \\
151748\end{array}$ & $\begin{array}{l}1,2,2 \\
1,2,2 \\
1,2,3 \\
2,2,2\end{array}$ & $\begin{array}{r}67 \\
67 \\
67 \\
100\end{array}$ & & $\begin{array}{l}293197 \\
293194 \\
297907 \\
192905\end{array}$ & $\begin{array}{l}1,1,2 \\
2,1 \\
0,0,0,1 \\
0,0,0,1\end{array}$ & $\begin{array}{r}67 \\
0 \\
100 \\
100\end{array}$ \\
\hline & $\begin{array}{l}40213 \\
286971\end{array}$ & $\begin{array}{l}2,2,2,3,3 \\
2,2,3\end{array}$ & $\begin{array}{l}100 \\
100\end{array}$ & Penicillium sp. & $\begin{array}{l}19759 \\
91944 \mathrm{iii}\end{array}$ & $\begin{array}{l}3,3,3 \\
0,2\end{array}$ & $\begin{array}{r}100 \\
0\end{array}$ \\
\hline
\end{tabular}

The two isolates of (a) P. atramentosum (IMI 210922) grouped in subcluster $1 \mathrm{~b},(b) P$. solitum var. crustosum (91939) in subcluster $2 \mathrm{c}$ and (c) P. brevicompactum (17456) in $3 \mathrm{f}$. One isolate of $P$. echinulatum (68236) grouped in 3a, and the other was negative for pectinase and amylase (Table 1). This gives a consistency value of $75 \%$ for these four strains for amylase which is the same as that for pectinase for all tested strains (see above).

\section{Enzyme bands/patterns}

Eleven strains gave negative results for both pectinase and amylase (Table 1). Schematic drawings of pectinase patterns/bands obtained from the other strains are given in Fig. 1. Seven PG patterns were observed. The most common patterns were a-d. Some strains produced 
R. R. M. PATERSON AND OTHERS

\section{Percentage similarity}

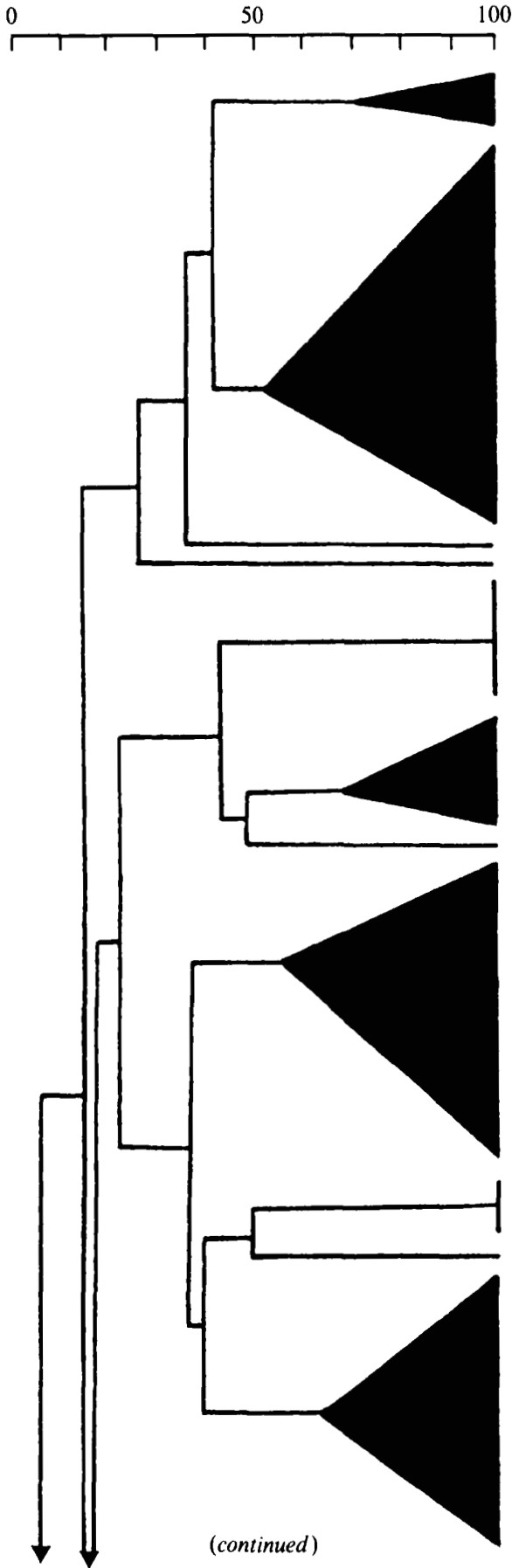

Cluster Species represented and no. no. of strains present

Ia

P. solitum var. solitum 3

$P$. solitum var. crustosum

P. expansum

$P$. atramentosum

P. aurantiogriseum

P. citrinum

16

$P$. solitum var. solitum

$P$. viridicatum

Penicillium sp.

$P$. solitum var. crustosum

$P$ atramentosum

P. citrinum

$2 a i$

P. solitum var. crustosum 2

\section{P. citrinum}

P. solitum var. solitum

$P$. solitum var. crustosum

P. aurantiogriseum

P. granulalum

$2 c$

solitum var solitum 4

P. solitum var. crustosum 12

P. aurantiogriseum

$P$. solitum var. solitum

Penicillium sp.

$2 \mathrm{e}$

Penicillium sp.

$P$. aurantiogriseum

P. breticompactum

21

7

P. solitum var. solitum 4

Penicillium sp. 


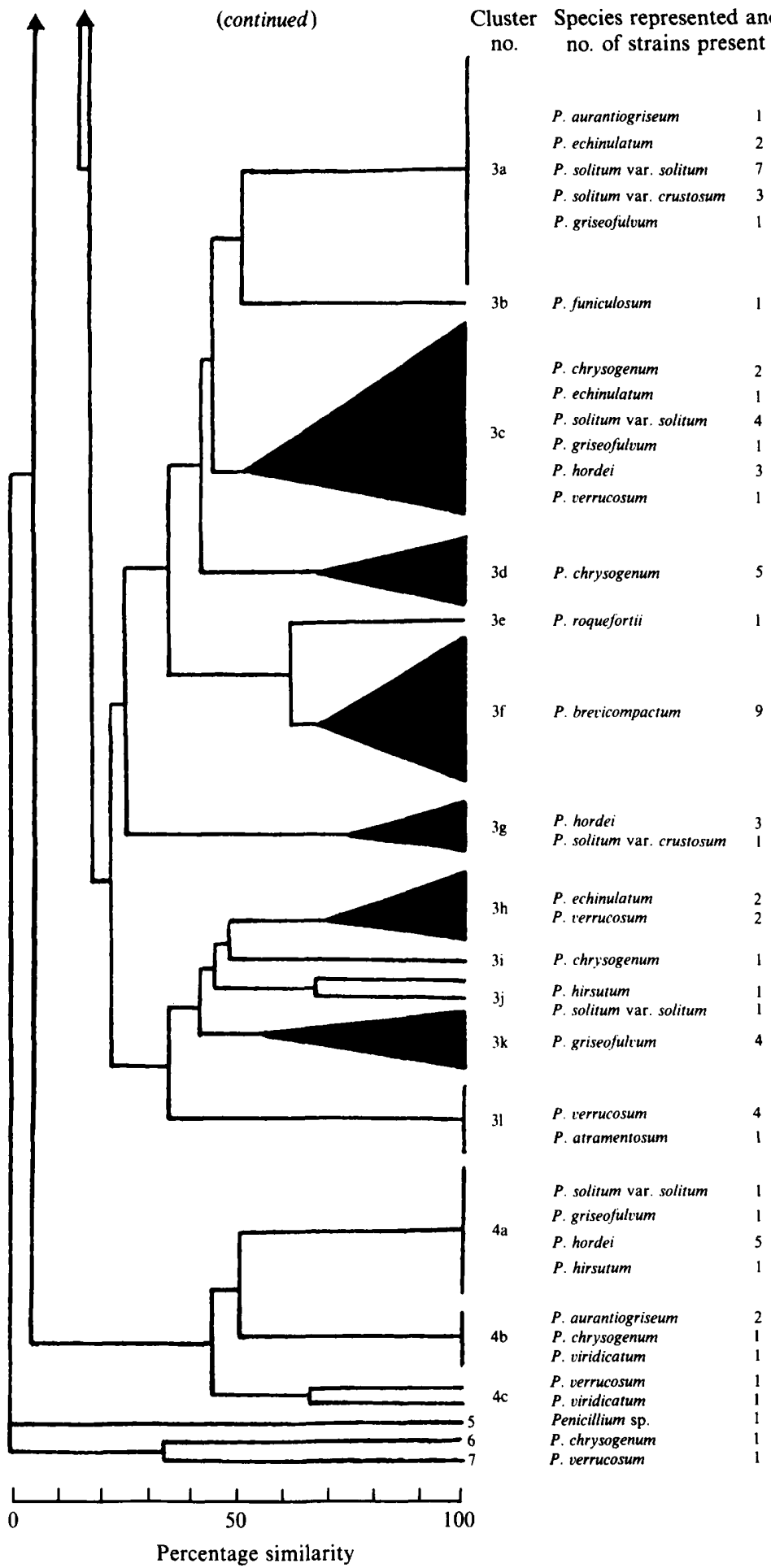

Fig. 2. UPGMA phenogram of strains. A data matrix was constructed of 20 enzyme bands or patterns (characters) and 160 strains (OTUs); resemblances were calculated using Jaccard's coefficient ( $S_{\mathrm{J}}$ ), and clustered by average linkage (UPGMA). Cluster determination is described in Methods. 
Table 3. Subclusters in which each species is represented and the percentage of strains of each species in the subcluster

$n$ is the number of strains studied of each species. Species names followed by a number in parentheses indicate the species cluster in Bridge et al. (1989). Subclusters in which only one species is represented are denoted by an asterisk $\left(^{*}\right)$.

\begin{tabular}{|c|c|c|c|c|c|}
\hline Species & $n$ & $\begin{array}{c}\text { Subclusters, percentage } \\
\text { of strains }\end{array}$ & Species & $n$ & $\begin{array}{l}\text { Subclusters, percentage } \\
\text { of strains }\end{array}$ \\
\hline $\begin{array}{l}\text { P. atramentosum } \\
P . \text { aurantiogriseum (4) } \\
\text { P. aurantiogriseum (6) } \\
P . \text { brevicompactum } \\
P . \text { chrysogenum (7) } \\
P . \text { chrysogenum (14) } \\
\text { P. citrinum } \\
\text { P. echinulatum } \\
\text { P. expansum (1) } \\
\text { P. expansum (2) } \\
\text { P. expansum (3) } \\
\text { P. funiculosum } \\
P . \text { granulatum } \\
\text { P. griseofulvum }\end{array}$ & $\begin{array}{l}5 \\
3 \\
2 \\
1 \\
1 \\
8\end{array}$ & $\begin{array}{l}\text { lb, } 67 ; 1 \mathrm{~d}, 17 ; 31,17 \\
2 \mathrm{f}, 33 ; 4 \mathrm{~b}, 33 ; 2 \mathrm{~b}, 16 ; \\
3 \mathrm{a}, 16 \\
1 \mathrm{~b}, 50 ; 2 \mathrm{~d}, 50 \\
3 \mathrm{f}, 82 ; 2 \mathrm{f}, 18 \\
3 \mathrm{~d}, 67 ; 3 \mathrm{i},{ }^{*} 33 \\
3 \mathrm{~d}, 43 ; 3 \mathrm{c}, 29 ; 4 \mathrm{~b}, 14 ; \\
6, * 14 \\
2 \mathrm{a}, 67 ; 1 \mathrm{~b}, 33 \\
3 \mathrm{a}, 33 ; 3 \mathrm{~h}, 33 ; 3 \mathrm{c}, 16 ; \\
\text { negative, } 17 \\
2 \mathrm{f}, 100 \\
\text { lb, } 100 \\
2 \mathrm{f}, 100 \\
3 \mathrm{~b} \\
2 \mathrm{c} \\
3 \mathrm{k}, 50 ; 3 \mathrm{a}, 13 ; 3 \mathrm{c}, 13 ; \\
4 \mathrm{a}, 13 ; \text { negative, } 13\end{array}$ & $\begin{array}{l}P . \text { hirsutum } \\
P . \text { hordei } \\
P . \text { olivinoviride } \\
P . \text { roquefortii } \\
P . \text { solitum var. } \\
\text { crustosum } \\
\text { P. solitum var. } \\
\text { solitum } \\
\text { P. verrucosum }\end{array}$ & $\begin{array}{r}2 \\
11 \\
1 \\
1 \\
24\end{array}$ & 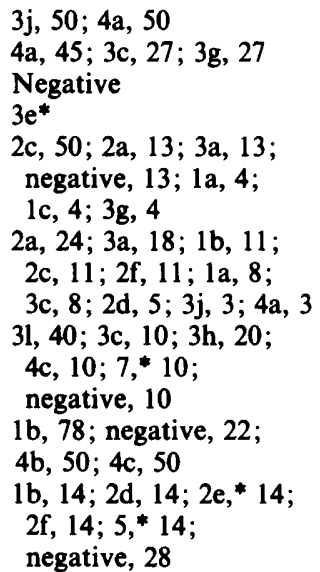 \\
\hline
\end{tabular}

patterns $a$ and $b$, whereas other strains produced either $a$ or $b$. Six distinct bands were observed in the case of the amylase patterns, and some strains produced a combination of more than one of these bands (Table $4 ;$ Fig. 3 ). The $R_{F}$ values for the amylase bands were: band 1 , $0.07 ; 2,0.34 ; 3,0.48 ; 4,0.59 ; 5,0.22 ;$ and $6,0.71$.

\section{Clusters/subclusters}

The dendrogram (Fig. 2) indicated little correlation between the pectinase and amylase patterns for strains and the species concepts devised by Bridge et al. (1989). The dendrogram can be divided into seven clusters, and each of these into subclusters. Strains are listed in Table 1 in the order of the dendrogram, and strains forming the clusters and subclusters are shown. The percentage of strains of each species in subclusters are also given in Table 3. Table 3 indicates how each species is distributed in the dendrogram. The enzyme patterns/bands which characterize the clusters are provided in Table $4(a)$ and subclusters in Table $4(b)$.

The representative enzyme pattern of cluster 1 was PG pattern $c$, with the majority of strains also producing PE pattern A, and amylase band 1 (Table $4 a$ ). Cluster 1 contained all the $P$. expansum and $P$. viridicatum strains from clusters 2 and 27 respectively of Bridge $e t$ al. (1989), except for the two negative $\boldsymbol{P}$. viridicatum strains. In addition, most strains of $\boldsymbol{P}$. atramentosum were included. Subcluster la contained four $P$. solitum strains with substantially different isozyme patterns from other $P$. solitum strains. Subcluster $1 \mathrm{~b}$ contained all $\boldsymbol{P}$. expansum, $P$. viridicatum and most $P$. atramentosum strains mentioned above, together with some other strains. Subclusters $1 \mathrm{c}$ and $1 \mathrm{~d}$ consisted of a strain of $P$. solitum var. crustosum and one of $P$. atramentosum respectively (Tables 1 and 3 ; Fig. 2).

Cluster 2 was composed of strains which produced $P G$ a and/or $b$, and most produced amylase band 1 (Table $4 a$ ). All remaining $P$. expansum, and most $P$. solitum var. crustosum and $P$. citrinum strains were in cluster 2 . Subcluster $2 \mathrm{a}$ was composed of low-enzyme-producing strains of $P$. solitum (both varieties), and two $P$. citrinum strains. It is divided into 2 ai and 2aii in the dendrogram (Fig. 2) to indicate that the subgroup is heterogeneous. Elsewhere 2a is treated as a single subcluster because $(a)$ similar strains are then grouped together, and $(b)$ the loosely linked $P$. aurantiogriseum is treated in a separate subcluster to emphasize the different enzyme patterns 
Table 4. Distribution of enzyme activities among strains

Column headings: CL, cluster number in dendrogram (Fig. 2); PG, polygalacturonase; PE, pectin esterase; PL, pectin lyase; $n$, number of strains in each cluster. a-j, A, B, C and I, and $1-6$ refer to the enzyme patterns and bands (Figs 1 and 3).

(a) Percentage of strains in each cluster that produced the various enzyme activities

Note that only one strain is represented in each of clusters 5-7.

\section{Pectinase}

\begin{tabular}{|c|c|c|c|c|c|c|c|c|c|c|c|c|c|c|c|c|c|c|c|c|}
\hline \multirow[b]{2}{*}{$\mathrm{CL}$} & \multicolumn{9}{|c|}{ PG } & \multicolumn{3}{|c|}{ PE } & \multirow{2}{*}{$\overbrace{I}^{P L}$} & \multicolumn{6}{|c|}{ Amylase } & \multirow[b]{2}{*}{$n$} \\
\hline & $a b$ & $\mathrm{c}$ & d & e & f & $\mathbf{g}$ & $\mathbf{h}$ & $\mathrm{i}$ & $\mathrm{j}$ & A & B & $\mathrm{C}$ & & 1 & 2 & 3 & 4 & 5 & 6 & \\
\hline 1 & 0 & 97 & 0 & 0 & 0 & 0 & 0 & 0 & 0 & 78 & 0 & 0 & 11 & 63 & 18 & 7 & 0 & 4 & 0 & 27 \\
\hline 2 & 100 & 0 & 0 & 0 & 4 & 0 & 0 & 0 & 0 & 25 & 4 & 0 & 0 & 63 & 13 & 8 & 0 & 0 & 0 & 53 \\
\hline 3 & 0 & 0 & 21 & 6 & 0 & 3 & 2 & 6 & 17 & 6 & 0 & 0 & 0 & 90 & 5 & 28 & 9 & 6 & 2 & 63 \\
\hline 4 & 0 & 0 & 100 & 0 & 0 & 0 & 0 & 0 & 0 & 36 & 0 & 0 & 14 & 0 & 0 & 0 & 0 & 0 & 0 & 14 \\
\hline 5 & 0 & 0 & 0 & 0 & 0 & 100 & 0 & 0 & 0 & 0 & 0 & 0 & 0 & 0 & 0 & 0 & 0 & 0 & 0 & 1 \\
\hline 6 & 0 & 0 & 0 & 0 & 100 & 0 & 0 & 0 & 0 & 0 & 0 & 0 & 0 & 0 & 0 & 0 & 0 & 0 & 0 & 1 \\
\hline 7 & 0 & 0 & 0 & 100 & 100 & 0 & 0 & 0 & 0 & 0 & 0 & 100 & 0 & 0 & 0 & 0 & 0 & 0 & 0 & 1 \\
\hline
\end{tabular}

(b) Percentage of strains in each subcluster that produced the various enzyme activities

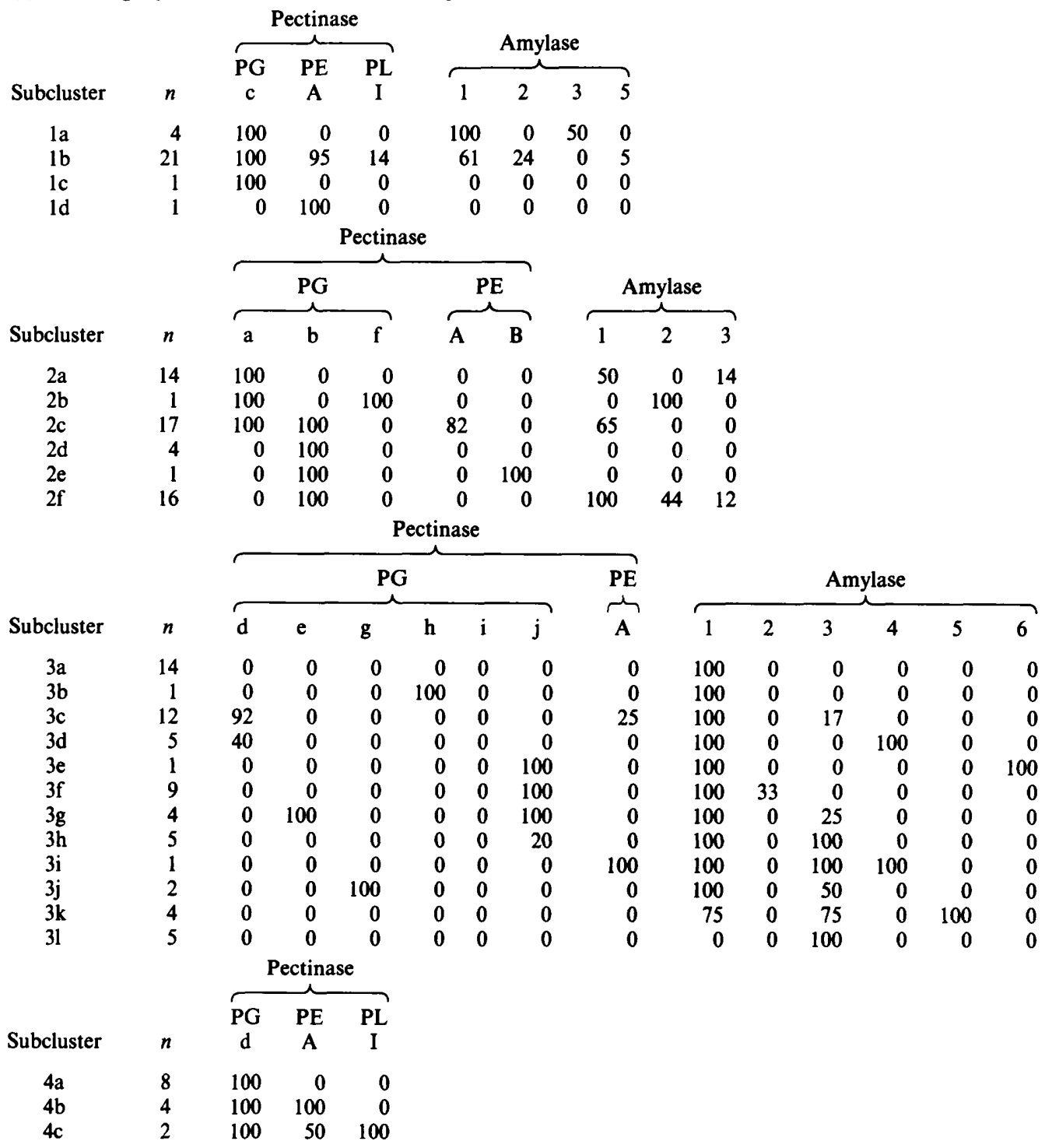




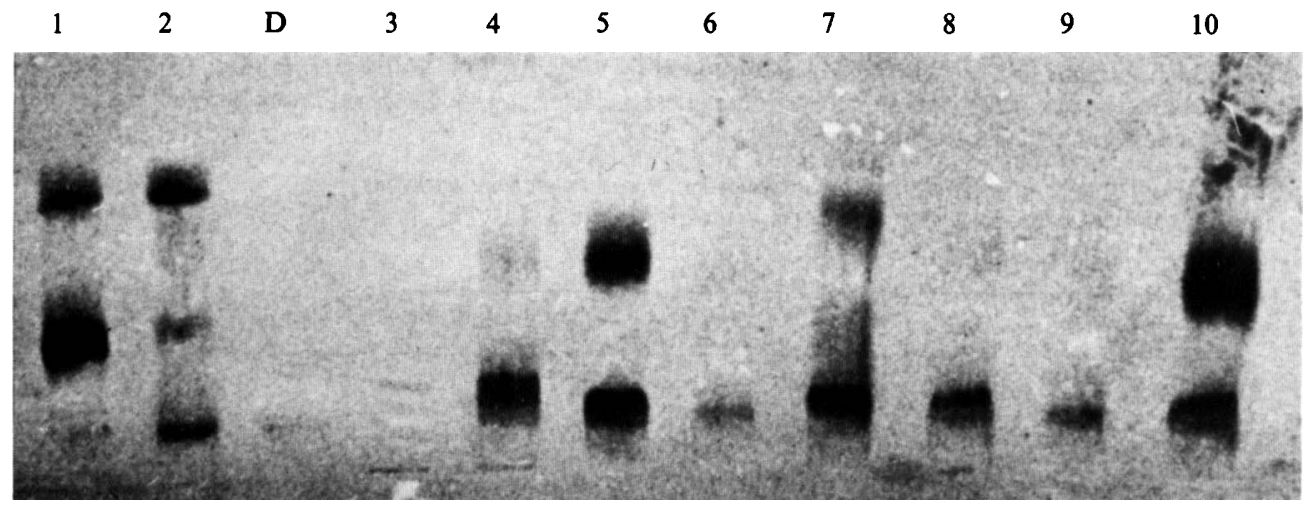

Fig. 3. Negative photograph (to improve contrast) of an amylase gel. Lane 1, $P$. griseofulvum IMI 28808 (bands 3 and 5); 2, P. griseofulvum 39809 (bands 1,3 and 5); D, dye; 3, P. citrinum 39812 (inadequate); 4, P. aethiopicum 285524 [bands 1 and 2 (weak)]; 5, P. brevicompactum 297950 (bands 1 and 2); 6, unknown 19759 (inadequate); 7, P. hirsutum 196570 (bands 1 and 3); 8, P. solitum var. solitum 297969 (band 1); 9, P. expansum 285521 (band 1); 10, P. expansum 297959 (bands 1 and 2).

produced by this strain (Table $4 b$ ). By far the largest grouping of $P$. solitum var. crustosum strains clustered in $2 c$, indicating that this enzyme pattern is typical of this taxon, although four strains of $P$. solitum var. solitum, and the only strain of $P$. granulatum tested were included. Subcluster $2 \mathrm{c}$ was distinguished by production of the PG pattern $a+b$, with a high proportion of PE pattern $A$, and the majority produced amylase band 1 (Table $4 b$ ). Subcluster $2 \mathrm{~d}$ is a heterogeneous collection of strains without detectable amylase, and with low pectinase production. The unidentified strain IMI 19759 did not cluster in 2e. All the cluster 2 (Bridge et al., 1989) $P$. expansum strains clustered in $2 \mathrm{f}$, although it contained strains referred to as three other species, and one unknown.

Amylase pattern 1 was the most common in cluster 3. Low frequencies of PE activity, various PG bands, and multiple amylase bands (Table $4 a$ ) were also apparent. Therefore, it is more heterogeneous than the other clusters (see Discussion). Cluster 3 contained all the $P$. echinulatum strains (except for one negative strain), P. chrysogenum (cluster 7; Bridge et al., 1989), most $P$. brevicompactum, $P$. griseofulvum, $P$. verrucosum and $P$. chrysogenum strains (cluster 14; Bridge et al., 1989), and $P$. hordei strains (cluster 13; Bridge et al., 1989). Subcluster 3a contained largely $P$. solitum strains (both varieties) with inadequate pectinases. Non-fasciculate strain $P$. funiculosum clustered separately in $3 \mathrm{~b}$. Subcluster $3 \mathrm{c}$ was a heterogeneous group with high levels of enzyme. Cluster $3 \mathrm{~d}$ is exclusively of $P$. chrysogenum strains; however, it contained strains from both clusters of the taxon recognized by Bridge et al. (1989). All strains produced amylase pattern 4 which was unique to $P$. chrysogenum strains (see also $P$. chrysogenum subcluster 3 i) (Table $4 b$ ). The $P$. roquefortii strain clustered exclusively in $3 \mathrm{e}$, because it produced the unique amylase band 6 . Cluster $3 \mathrm{f}$ contained exclusively $P$. brevicompactum strains. Cluster $3 \mathrm{~g}$ consisted of mainly $P$. hordei strains and was characterized by the unique pectinase band $\mathrm{e}$. Subgroup $3 \mathrm{~h}$ was a more heterogeneous group consisting of strains with possible higher ploidy levels and/or heterokaryons (see Discussion). Subcluster $3 \mathrm{i}$ was a single strain of $P$. chrysogenum with a complex amylase pattern of three bands including band 4 (see above). It probably has a different genetic constitution to subcluster $3 \mathrm{~d}$ (see Discussion). Subcluster $3 \mathrm{j}$ contained two strains with the unusual PG pattern $\mathrm{g}$ (see also cluster 5). Four strains of $P$. griseofulvum with multiple and unique amylase bands formed subcluster $3 \mathrm{k}$, indicating an unusual genetic constitution. Subcluster 31 contained predominantly $P$. verrucosum strains and had the unique amylase pattern of band 3 only (Tables 1,3 and $4 b$; Fig. 2).

Cluster 4 consisted of strains which gave inadequate amylase activity. Splitting of the cluster on the basis of different pectinase activities might be inappropriate. However, subcluster $4 \mathrm{a}$ 
contained the largest number of $P$. hordei strains compared to others, and cluster $4 \mathrm{~b}$ and $4 \mathrm{c}$ were mixed, although they contained both of the $P$. viridicatum (cluster 28 ; Bridge et al., 1989) strains studied.

The remaining three strains clustered separately in subclusters $5-7$, implying considerable differences in these strains.

\section{DISCUSSION}

The main problems with the method were variation in intensity of enzyme activity in repeated runs with some strains, and variation in intensity and pattern shape produced by some strains of the same species. The method is useful especially for higher enzyme producers which produce clear patterns. Lower enzyme producers did not give detectably lower amounts of growth, and so were not necessarily attenuated strains, and were probably better adapted for growth on the media than the higher enzyme producers.

Pattern shapes and $R_{F}$ values of bands were similar in those strains where consistent positive enzyme intensity was observed. However, it is possible that patterns a or b were simply weak $a+b$ patterns, rather than each being one component of the more complex pattern, as was assessed in this study (Fig. 1). Clusters and subclusters were separated occasionally on the basis of non-detection of a band rather than a positive character, and can separate otherwise similar species (e.g. subclusters $2 \mathrm{c}$ and $3 \mathrm{a}$; Fig. 2, Table $4 b$ ), and variation in enzyme intensity could be involved.

Protein determinations were not undertaken since they would not standardize the activity of the isozymes being tested. It would be more appropriate to use equal volumes of culture fluid in this case. Table 2 shows that most strains give consistent results, e.g. Penicillium sp. (IMI 19759) and $P$. hordei (40213), which indicates strongly that the variation is not because of the technique per se, but is a property of some strains. Differences in inoculum size were probably not the main source of variation since most strains were consistent producers after testing (up to five times in some cases). Variation also was species specific. For example, both $P$. brevicompactum and $P$. hordei gave mean percentage consistency values of 80 and $78 \%$ respectively, whereas $P$. viridicatum gave a value of $68 \%$. The figure for all strains tested was 75 . This indicates that $P$. viridicatum is a particularly variable species for this character. Variation in isozyme patterns within fungus species is well-recognized (Hepper et al., 1988).

Aneuploidy and polyploidy have been suggested as possible explanations for variation (Mays et al., 1979; Tolmsoff, 1983; Bridge et al., 1987), and these mechanisms, and true heterokaryosis, would explain some of the isozyme differences, and account for the low reproducibility of some strains. Many of these phenomena could be explained by the existence of the parasexual cycle in strains.

Additional taxonomic and genetic information can be obtained from isozyme analysis by a locus-to-locus rather than a band-to-band comparison, and its use to analyse the genetic constitution of fungi has been reviewed recently (Micales et al., 1986). However, some of the patterns obtained from pectinase activity are unusual both in this study (Fig. 1) and as reported by Cruickshank \& Pitt (1987). The enzymes often formed patterns and not bands making a genetic interpretation of the data difficult. A possible exception is pattern a and/or b (Fig. 1). More work is needed with that system to enable more-definite genetic interpretations of these patterns to be given. The unusual nature of the patterns may be the result of the action of the different pectinase enzymes (PG, PE and PL) acting in concert; the absorption of the protein samples to polyelectrolytes, such as pectin fragments; and/or from the complicated genetic constitution of these fungi (Mays et al., 1979).

The amylase bands are more amenable to a genetic interpretation because typical bands were produced (Fig. 3). Many strains produced one band (band 1), and were probably monomorphic for amylase. However, some strains produced two bands and it is possible, for example, that they are not haploid, the enzyme being coded by two alleles at a single locus, assuming that the enzyme is monomeric. Alternatively, the strains might be at least dikaryotic with different loci in each nucleus. For example, of the four 'atypical' $P$. solitum strains in subcluster 1a, two (169087a and 297892) produced two amylase bands whereas the other two strains produced one. 
A maximum of three bands was observed in some cases from other strains (e.g. Fig. 3), which is consistent with diploid strains with two alleles at a single locus for a dimeric enzyme (Micales $e t$ al., 1986).

Most of the non- $P$. expansum strains in subcluster $2 \mathrm{f}$ (Table 1) produced more than one amylase band (Table $4 b$ ), and might be of a different genetic constitution, either not haploids, or heterokaryons. Subcluster $2 \mathrm{f}$ could be split into two groups with a separate group $(2 \mathrm{~g})$ for the seven multiple amylase producers.

The exclusive production of amylase band 1 or band 3 might represent the homoallelic nature of the amylase loci in these cases, whereas the production of both band 1 and band 3 would conform to the heteroallelic nature of the loci (Mays et al., 1979). It is interesting that the only group which produced exclusively band 3 was subcluster 31 , which is predominantly composed of $P$. verrucosum strains. The heterogeneous nature of cluster 3 is confirmed by the significantly different DNA base distributions of representatives from cluster 3 compared to those from the other groups (Paterson et al., 1989 and Table 1).

With the exception of the early, and largely unrelated work of Garber \& Behara (1966), the only genetic studies using isozyme patterns in Penicillium involved heterokaryons artificially formed through protoplast fusion (Anné \& Peberdy, 1981). Genetic analysis in Penicillium is complicated by a lack of basic information. For example, it is not known which strains $(a)$ are homo- or heterokaryotic, and/or (b) have different ploidy levels. The chromosome numbers are not known for most species, although $P$. chrysogenum is reported to have six (Ball, 1971; Crackower \& Bauer, 1971). Considerable phenotypic variation has been reported between single conidium isolates of some strains, which apparently correlates with DNA content (Bridge et al., 1986, 1987), which has considerable implications when attempting to standardize inocula (see earlier).

This work was carried out as part of the Science and Engineering Council contract SO/17/84, Systematics of Microfungi of Biotechnological and Industrial Importance. Professor E. A. Bell, Dr L. E. Fellows and the Royal Botanic Gardens, Kew are thanked for the use of equipment, Ms P. Farnell for technical assistance, and Mrs P. Wiltshire for discussions.

\section{REFERENCES}

ANNÉ, J. \& PEBERDY, J. F. (1981). Characterization of inter-specific hybrids between Penicillium chrysogenum and $\boldsymbol{P}$. roqueforti by isoenzyme analysis. Transactions of the British Mycological Society 77, 401-408.

Ball, C. (1971). Haploidization analysis in Penicillium chrysogenum. Journal of General Microbiology 66, 63-69.

Bridge, P. D., Hawksworth, D. L., Kozakiewicz, Z., ONions, A. H. S. \& Paterson, R. R. M. (1986). Morphological and biochemical variation in single isolates of Penicillium. Transactions of the British Mycological Society 87, 389-396.

Bridge, P. D., Hudson, L., Kozakiewicz, Z., Onions, A. H. S. \& Paterson, R. R. M. (1987). Investigations of variation in phenotype and DNA content between single-conidium isolates of single Penicillium strains. Journal of General Microbiology 133, 996-1004.

Bridge, P. D., Hawksworth, D. L., Kozakiewicz, Z., Onions, A. H. S., Paterson, R. R. M., SACKin, M. J. \& SNEATH, P. H. A. (1989). A reappraisal of terverticillate penicillia using biochemical, physiological and morphological features. I. Numerical taxonomy. Journal of General Microbiology 135, 2941-2966.
Crackower, S. \& Bauer, H. (1971). Mitosis in Penicillium chrysogenum and Penicillium notatum. Canadian Journal of Microbiology 17, 605-608.

Cruickshank, R. H. \& Wade, G. C. (1980). Detection of pectin enzymes in pectin-acrylamide gels. Analytical Biochemistry 107, 177-181.

Cruickshank, R. H. \& PitT, J. I. (1987). Identification of species in Penicillium subgenus Penicillium by enzyme electrophoresis. Mycologia 79, 614-620.

Garber, E. D. \& Beraha, L. (1966). Genetics of pathogenic fungi. Pectolytic enzymes of virulent and avirulent strains of 3 phytopathogenic penicillia. Canadian Journal of Botany 44, 1645-1650.

Hamamoto, M., Sugiyama, J., Goto, S. \& Komagata, K. (1986). Numerical taxonomy based on the electrophoretic mobility of enzymes in the genera Rhodosporidium, Cystofilobasidium and Rhodotorula. Journal of General and Applied Microbiology 32, 89-99.

Hepper, C. M., Sen, R., Azcon-Aguilar, C. \& GRACE, C. (1988). Variation in certain isozymes amongst different geographical isolates of the vescicular-arbuscular mycorrhizal fungi Glomus clarum, Glomus monosporum, and Glomus mosseae. Soil Biology and Biochemistry 20, 51-59.

MAYS, B., ROBERTS, D. W. \& SOPER, R. S. (1979). 
Intraspecific genetic variability in laboratory strains of Entomophthora as determined by enzyme electrophoresis. Experimental Mycology 3, 289-297.

Micales, J. A., Bonde, M. R. \& Peterson, G. L. (1986). The use of isozyme analysis in fungal taxonomy and genetics. Mycotaxon 27, 405-449.

Paterson, R. R. M., KIng, G. \& Bridge, P. D. (1989). High resolution melting curves of DNA from 14 Penicillium strains. Mycological Research (in the Press).
Smith, D. \& Onions, A. H. S. (1983). The Preservation and Maintenance of Living Fungi. Kew: Commonwealth Mycological Institute.

SNEATH, P. H. A. \& SOKAL, R. R. (1973). Numerical Taxonomy. San Francisco: W. H. Freeman.

TolmsofF, W. J. (1983). Heteroploidy as a mechanism of variability among fungi. Annual Review of Phytopathology 21, 317-340. 